\title{
2 A Burmese perspective on prospects for progress
}

Khin Zaw Win

It has been said that history is written by the victors. In the same vein, progress can be said to be defined by who, or which side, is carrying it out. Superficially, a linear motion forwards is assumed, just as for the march of modernisation or of civilisation itself. But in reality, the very term 'progress' is a loaded one, and that it stands for a complex process.

It is not surprising, therefore, that attempting to define progress in Myanmar's case is a precarious undertaking. The incumbent regime steadfastly maintains that immense strides have been made since it assumed power in 1988, which is not untrue in a number of aspects. On the flip side-something that the opposition never tires of pointing out-there are other facets that are not causes for celebration. Any number of individuals and organisations base their assessments on the simple formula that lack of democracy equals lack of progress. In the face of such daunting circumstances and the complexity of the task, one has to pin down what could confidently be labelled progress. At the same time, instead of arguing about what it means or represents, a more productive endeavour would be to identify turning points- those 
that have passed and those that could come- that could, if handled properly, make a difference for the country.

The argument about progress is especially intense when it comes to the question of which direction and through whom such progress is to be made. The general direction indicated by the events of 1988 and their immediate aftermath was towards a democratic system and a market economy: in short, overturning the straitjacket system established by former Head of State Ne Win and his Burma Socialist Program Party (BSPP). But beyond that initial, universally agreed step, differences yawned wide. The opposition called for a speedy transition to democracy and, after the 1990 elections, an immediate transfer of power to an elected government-which meant a National League for Democracy (NLD) government. And ever since, whatever hopes there might have been for political progress were effectively sidelined by the running battle over the 'transition to a democratic government', a bitter wrangle over an endless series of issues. By extension, advances and improvements in other vital sectors are being held up.

It is especially ironic for a country as badly in need of development as Myanmar to find itself blocked by a political process proclaiming its devotion to the betterment of the country. The change over to a democratic system espoused by the main opposition is very much along the lines of the liberal consensus model. It should be clear by now that this has run into two main difficulties.

Firstly, there is increasing evidence in developing countries that rises in per capita income precede the emergence of democracy and not the other way around; and that good governance, far from being a precondition for rapid growth, is typically an outcome of successful economic development (Khan 2004). There is a convincing case for poverty and lack of economic development being the context- together with internal conflict-in which poor leadership played itself out in Myanmar's earlier experiment with democracy. Developing country status conferred in late 1987, to which is added the destruction and dislocation of 1988, does not augur well for the prospects of a quick jump to democracy. Amazingly enough, precisely such an opportunity 
opened up in September 1988 when the BSPP government was on its last legs, only to be passed over by the leadership of the democracy movement. There have been others in subsequent years, but none of these were taken advantage of. The prospects themselves were there-as they are now-but turning them into reality was another matter.

This brings us to the second difficulty, one that is directly related to the NLD and stems from the way it has played its cards. Besides the precariousness of the preconditions for democracy, the NLD's strategyor lack of one-has practically written off the tenability of the liberal consensus approach to building democracy in Myanmar. This has come about because one individual's wishes have been allowed to fashion an entire action plan for democracy. Moreover, this is a plan that, to force through a political settlement, does not hesitate to call for economic measures to be taken against a country struggling to develop itself.

The 18-year political tussle in Myanmar between the military government under the State Peace and Development Council (SPDC) and the democratic opposition has undoubtedly dragged on for far too long, and there are indications that, by the very fact of its lengthy unproductiveness, it has made itself almost irrelevant to the majority of the population. The much-touted and long-proposed solution from the main opposition party has itself become a problem. The times now cry out for a 'second opinion' of what is really ailing Myanmar, and therefore for a fresh, more effective, line of treatment.

Meanwhile, the country continues to reel from the effects of a poorly managed transition from a centrally planned economy. This has been exacerbated by sanctions imposed by the West. For many people, the difficulties of daily existence have meant that political issues receive less attention and priority, particularly with the untenable nature of the present democratic alternative.

Against this backdrop, an assessment of prospects for progress could begin with peace agreements.

The winding down (which began in 1989) of the civil conflict is an event that is under-acknowledged and underrated. Besides that, it has not been well integrated with the concomitant democratic transition 
and, more importantly, post-conflict political needs have not been attended to. One could say that the promise of the 1947 Panglong Agreement-which many perceive to have been betrayed, and hence the cause of the decades-long ethnic minority rebellions - is being given renewed attention. The ethnic nationalities expect nothing less.

That the majority of the cease-fire agreements continue to hold can be seen as a vote of confidence in the present government, as well as attesting to the exhaustion (in all senses) of armed rebellion as a mode of political action. Nevertheless, the peace agreements have not been followed up satisfactorily. Moreover, the democratic opposition has been equivocal about them. The prolongation of the political stand-off has meant that pockets of armed conflict persist in the country, with all the negative consequences that attend in their wake. The final cessation of conflict should have occurred earlier, were it not for the absence of a settlement among the main actors in the capital.

It has been a lost decade for democracy in Myanmar, and needlessly so. Democratisation is going to take longer and the Third Wave in Myanmar is being drawn out. Does that mean that development is to be drawn out, too? And would not devolution of governance be needed as much as or even more than democracy, because minorities and smaller parties have little to gain from majoritarianism in whatever garb it arrives? Consociational democracy, ${ }^{1}$ which has been adopted successfully in other countries in the region, is still some way off. The new constitution being drawn up now, controversial as it is, does provide for 14 sub-national administrations and legislatures as well as six smaller bodies for autonomous regions.

When centre-periphery and majority-minority relations in Myanmar are considered, the way that Bamar or Burman (majority) politics has impacted on minorities is a crucial but little studied issue. Now for the first time, prevailing realities are bringing about a system that is not wholly majority centred.

No matter how the new constitution is viewed, there is no denying that a good deal of decentralisation and devolution of power is going to take place, and this could precede democratisation. In the present 
context, devolution would appear to promise more pluralism and ultimately a sounder democracy in the future. In other words, the greater exercise of democracy at the provincial level would pave the way for eventual full liberalisation at the national level. In Myanmar's case, this would be a sound and workable formula.

The unavoidable issue, then, is to ensure that the ethnic groups are equal to the task. There is a need for people in the states to build up their capacity to participate in governance. The standard and oftproclaimed statement that democracy will solve everything does not apply here-or anywhere else for that matter. Stepped-up development in the ethnic states - including the cease-fire areas - has been going on for more than a decade. This part of the peace dividend could have been more fruitful were it not for the throttling of development assistance and investment from abroad.

\section{The main democratic opposition: a penchant for losing opportunities}

The main opposition continues with its fixation on elections, particularly the 1990 elections, which were but one event in the transition. By doing so, it is destroying its own credibility, and the difficulties this causes have spilled over to the democratic movement as a whole. Other than those espousing the extreme hard line in the regime, no one would like to see the main opposition organisation totally excluded. Despite rumours to the contrary, the NLD is being allowed to continue as a legal political party. It has a place in Burmese politics, no doubt, but that place is going to be different from what the organisation imagines it is entitled to. If it refuses yet again to face up to reality, it would be assuring its own extinction. It will be undergoing an involuntary make over; and its new niche will be the product of a process of triangulation effected by the military, the country's situation and its own capability. It is like water finding its own level.

There have been at least four notable, '24-carat' opportunities for the opposition leadership since 1988. These were not flashes in the 
pan; they were solid, serious openings that stretched on for months, if not years.

The first was from January to May of 1989. From about the time of the death of Daw Khin Kyi, General Aung San's widow, the then chairman of the ruling military council, General Saw Maung, made a sustained conciliatory overture to the democratic forces (which were very strong at that time). His gesture was aimed particularly at Aung San Suu Kyi.

After Aung San Suu Kyi's first period of house arrest and the ouster of General Saw Maung in April 1992, a second opening emerged, beginning with the removal of restrictions against Aung San Suu Kyi in July 1995. Not only was this opening thrown away, it was turned into a long period of skirmishes during which Aung San Suu Kyi attempted many variations on the confrontation theme and the military tried to contain her.

Particular mention should be made of the talks that the military council proposed to the leadership of the NLD (minus Aung San Suu Kyi) in September 1999. These talks were scuttled at the last minute when the NLD leadership followed Aung San Suu Kyi's request and refused to attend.

The third opportunity came after the failed coup attempt by exparty chairman Ne Win's family in March 2002. More will be said on this below.

The final window opened between May 2002 and May 2003. Following on from the efforts of the United Nations through its Special Envoy and those of Western countries, restrictions on Aung San Suu Kyi were again lifted. General Than Shwe reportedly did this despite grave reservations on the part of Generals Maung Aye and Khin Nyunt.

Although it was not made public at the time, there had been meetings between Aung San Suu Kyi and General Than Shwe, together with other high-level talks with some members of the Cabinet. Unparalleled opportunities had in fact been provided. If anything resembling the NLD statement of 12 February 2006 had been issued at that juncture (that is, three years ago), Myanmar's political and economic fortunes 
could have been so much different. It is regrettable that Myanmar's democratic transition is going to take longer. The central cause of this delay is personal and individual.

Not only has the democratic leadership alienated the top echelons in the military, it has opened a wide gulf between it and the middleranking officer corps - a development with even greater implications for the future.

Beyond merely pushing an amicable settlement on the democratic transition out of reach, Aung San Suu Kyi's konfrontasi has precluded the intra-societal meeting of minds that is necessary to get a handle on the country's problems. The breakdown in inter-élite relations has led to a wider breakdown.

\section{The armed forces: breaking with the past}

With Senior General Than Shwe's assumption of the top military council post in 1992, there was a pronounced distancing from former strongman Ne Win's influence. Many people at the time believed that $\mathrm{Ne}$ Win still exercised control over the ruling establishment, particularly through the agency of his loyal protégé, Khin Nyunt. Any regime anywhere would have been hampered and threatened if it had to keep looking over its shoulder, so to speak, most of the time. In addition to the many pressures the regime was being subjected to, this dangerously unpredictable ex-dictator was lurking in the wings.

After Ne Win stepped down in 1988, members of his immediate family_his daughter, son-in-law and grandsons - were able to set up substantial business interests. They still had clout and could still throw their weight about, but eventually they came to realise that power was no longer their exclusive domain. Resentful of the new competition and of their interests gradually being relegated to the back burner, they plotted a coup to coincide with Armed Forces Day, on 27 March 2002. The authorities managed to nip this in the bud with a pre-emptive strike. Three military regional commanders, the chief of police and a number of lower-ranking military personnel were implicated and dismissed. 
The SPDC's handling of this threat appeared to offer justification for two things (which are really a continuum): the rationale for its rule since 1988 was placed on still firmer ground and its argument for a continued political role was strengthened. Testimony of some eloquence was furnished for the regime's protestations that it was providing political stability and laying the ballast for the country's road to democracy. It is hard to imagine a democratic government handling a crisis like this on its own.

Then, too, a singular lack of discrimination and sophistication had become apparent on the side of the democrats. In realising where a common threat lay, and in its extirpation, an avenue for reconciliation and the reforging of a relationship had opened up. But, again, it was passed over.

Later that same year, two lieutenant-generals-Win Myint and Tin Hla-invested with a brace of important positions, were unceremoniously axed. The ostensible reason was corruption, with the military business entity Myanmar Economic Holdings involved. Win Myint, however, was linked to $\mathrm{Ne}$ Win, and it is quite likely that power maneouvres figured in his dismissal.

Of all the generals who since 1988 had made their pitch on the national stage and then exited, none had been as powerful as Khin Nyunt. Hand-picked by Ne Win in the mid 1980s to head the intelligence organisation, he had grown in power as well as ambition. If he had been content to make the positions he had achievedintelligence chief, full general, prime minister-the pinnacle of his career, and planned to make way for a new generation, he would have enjoyed a statesman-like finale. It was quite plain, however, that he had his sights set on the presidency.

He had been steadily adding to and broadening his power base over the years. His strongest support outside intelligence and government circles came from certain of the ethnic paramilitaries and new business tycoons. His wife, too, had been the head of the two state-sponsored women's organisations. Khin Nyunt was behind some of the reforms that had taken place and there seemed the promise of more to come, but the wide categorisation of him and his camp as moderates, and the 
other bloc in the military as hard-liners, does not stand up. He did have the most international exposure of all the generals and thereby could not have missed the way the wind was blowing; on the other hand, he could have been carefully cultivating an image.

Notwithstanding the political identity make over that appears to have occurred, it should not be forgotten that the Defence Services Intelligence (DSI) under Khin Nyunt was one of the main props of successive authoritarian regimes. It was the major instrument of repression, particularly of the political opposition. One of its foremost tasks was the continuum of 'processing' democracy activists, from surveillance and arrest to interrogation, conviction and imprisonment. Over the decades, DSI had become the most powerful and feared organisation in the country and Khin Nyunt was its longest serving chief.

Even from the reasons publicised after his ouster, it can be gauged how intolerable he had become to the main echelons of the military. The accusations levelled against him included disobeying orders, corruption and failure to comply with regulations. The intelligence apparatus was described as being above the law and preying on the people. Yet, the DSI and Khin Nyunt were among Ne Win's more successful creations. Khin Nyunt's position as a Ne Win protégé and Western-trained intelligence officer-plus his ability—had brought him to the top. Gunning for the supreme state post, however, requires more than that. He knew this, and assiduously cultivated his image and popularity, but in the end things backfired. The dual contexts ultimately won over: the dissonance of the military intelligence chief in a professional, combat-hardened army that increasingly came to resent him; and heading the feared and hated secret police in a society in transition to a more liberal system.

The top echelons of the army are now going through another intricate and measured reordering and reconfiguration, even more so than before. The final line-up will take the State through the culmination of the National Convention, the drafting of the new constitution and the formation of the government under that constitution. An indication of who will fill the future top state posts is expected to become apparent as this process unfolds. 
It used to be that the military regional commanders (who are major generals) were moved into the Cabinet or promoted together in one batch. Now, in a first instalment on 13 May 2006, of the 13 military regional commanders, two were given senior military positions vested with the rank of lieutenant-general, while three were given ministerial portfolios. Of the remaining eight commanders, one was appointed to the newly created Naypyitaw Command, so seven should have been awaiting their future assignments. The delicacy of this present rearranging is reinforced by reports (albeit unconfirmed) that deputy prime-ministerships that have been vacant since late 2002 are to be filled.

There are extreme elements within the establishment who would like to return to a neo-authoritarian system, but there are also other elements who oppose this and who are unhappy with unfettered authoritarianism. This is quite a positive sign. The extremes on both sides-within the establishment as well as the democrats-have to be opposed.

A new generation in the military is coming to the fore; it could have come even earlier were it not for certain tensions, intra-institutional as well as in the body politic. It is natural to have high expectations of every new generation and the present case is no different; however, when it comes to dealing with the present stamp of democratic politics, it would be unrealistic to expect a drastic change.

\section{Opportunities forgone}

It is noteworthy at this point that the conclusions from a detailed, longterm study of transitions from authoritarian rule in Latin America and Southern Europe echo uncannily the Myanmar experience. ${ }^{2}$ In fact, they predate Myanmar's transition and, if they had been made known sufficiently, could have served as a guide. It is worthwhile to highlight the parallels, and even if the way to a successful, trouble-free progression was missed, at least it can reconcile Myanmar to its present predicament and offer some help.

The study's assertion that an active, militant and highly mobilised popular upsurge could be an efficacious instrument for bringing down 
a dictatorship, but could make subsequent democratic consolidation difficult and could provide a regression to more authoritarian rule, is remarkably prescient of Myanmar in 1988, to the extent of holding up a mirror to those events. It advises postponing for an undefined period the goal of an 'advanced democratic' transformation, pointing out the advantages and disadvantages of democratisation 'on an instalment plan'. It adds that by initially accepting the role of strong but loyal opposition, newly emergent parties could find that they have taken the best possible path to power, in terms of optimising their eventual electoral strength and minimising the immediate risk that they would be impeded from taking office by violence.

The final comments could give some indication of where Myanmar's political destination lies and offer some hope. It reminds us that the circumstances of the transition compel players to compete for space and pieces rather than struggling for the elimination of opposing players, and that political democracy is produced by stalemate and dissent rather than by prior unity and consensus (something that could come as a surprise to Burmese democrats). It emerges from the interdependence of conflicting interests and the diversity of discordant ideals, in a context that encourages strategic interaction among wary and weary actors. Transition towards democracy is by no means a linear or a rational process. There is simply too much uncertainty about capabilities and too much suspicion about intentions for that (O'Donnell 1986). It remains for the Burmese players to recognise this.

The democrats have missed tremendous chances in the past decade. There was a superb opportunity to establish a position-unheard of in 30 years - from which a political party and democratic leader could have positively influenced the Myanmar military institution, no mean task in itself. Furthermore, it could have laid the ground for the military-despite all the assorted hard-liners in it - to respect democracy and to respect a democratic civilian government. All this has now passed into the 'if only' realm.

It goes without saying that foremost among the hallmarks of good leadership is the ability to recognise and seize such opportunities. This, 
to Myanmar's detriment, did not happen. Instead what we witnessed was recourse to more of the same: an ingrained, even pathological fixation on drumming up a call to 'take to the streets' and to repeat the 1988 uprising. With Aung San Suu Kyi's continued dismissal of the overtures and opportunities proffered by the military council, it was inevitable that the SPDC would announce, as it did on 26 April 2006, that it would not negotiate with the NLD. Finally, common knowledge that the door has shut became officially declared policy. The expected closure of an option, however, signals the greater need to seek and work along other avenues.

For the polity as a whole, instead of an absolutist fixation on the individual, there is a need to work on systems, institutions, organisations and processes, all of which constitute the foundations of a viable and enduring democracy. When a heavily managed democracy is mentioned, it usually connotes perpetration by the military or other authoritarian system. But what if democracy comes to be heavily managed by a predominant democratic party? The continued invoking of the majority obtained in the 1990 elections could provide a platform in opposing the regime, but this majoritarian line also brings a hardening of views, an intolerance of diversity of opinions and the inability to cope with failings of leadership. What the country needs is a solution, not a litany of blame, demands and positions. A serious, committed search for answers is taking place, but regrettably not in the orthodox political organisations.

Like it or not, the case for 'tandem' governance has been strengthened. The elected and non-elected components of such a system can complement, balance, buttress and correct each other. The very fact of cohabitation spells the establishment of a relationship. At the very least, this could pre-empt the uncontrollable divergences that have plagued the country in the past.

The experiences of Thailand and Chile have shown that democratic consolidation is possible even under military-imposed authoritarian constitutions. In Chile, the authoritarian constitution was circumvented and put to work for a democratic purpose through an institutionalised 
party system, a tradition of rule of law and capable political leadership. The fact that these conditions are only minimally fulfilled in Myanmar could alone account for the poor showing of democratic consolidation.

The Chilean case study mentions that 'a minimum of democratic rights and institutions granted by the 1980 constitution have been skillfully used by able democratic agents to foster political competition, to a level that most scholars never thought possible'. The neoinstitutionalist claims that only the removal of authoritarian institutions would clear the way for democratic consolidation seem overstated.

The political system instituted by the 1980 constitution could be called a sub-minimal democracy. The review process since then, especially after reforms in 1989, illustrates a case of slow, negotiated transition from authoritarian governments that have not suffered military or political defeat.

Another lesson from this case study is that pro-democracy constitutional reforms result more from changing political interests and depolarisation of actors than from much-cherished democratic principles or strong political will. A systematic view of institutional change is proposed, rather than a linear or mechanical approach more congenial to neo-institutionalism (Esteban Montes and Vial 2005).

In this regard, it would certainly not be out of place to recall one of the central issues during the struggle for independence half a century ago. After World War II, bowing to realities and to the Atlantic Charter, London offered dominion status to its colony. The majority of the Bamar population, however, caught up in nationalist fervour and almost totally behind the leading party, the Anti-Fascist People's Freedom League, turned the offer down and demanded total and immediate independence. Even membership in the Commonwealth was declined. In the prevailing ardour, hopes and assumptions fed on each other, leading to expectations that self-government would work wonders; and there was a childlike faith in the national leadership. What was left out of the reckoning was a grasp of the indigenous political culture and the nature of the political élites. 
What ensued is common knowledge: all-out civil war in all its brutality, in a land that had been trying to rebuild from the ashes of World War II. There are consequences-political, military, ethnic and economic - that remain to this day. With sobering hindsight, quite a few people, even the communists, now privately admit that independence could have been postponed beneficially for five or so years.

Myanmar has been at the mercy of inept politics for far too long. The present contentious era has become the longest, most unproductive and damaging of all —so much so that political parties, leaders and processes have all lost credibility. The public comes to realise that politics as it is practised now is not providing the answers or a way forward. There is so much emphasis on democracy, while the extreme weakness in associative capital is disregarded. Because of this, parties, organisations and even the military have foundered repeatedly. The task ahead includes a salvage operation for the democratic movement as a whole.

With regard to the course that the present regime has embarked on, there could be scattered suggestions of citizens having to acquiesce or having to give up what is deemed to be an unequal struggle. But in the larger picture - the present national context — there really is no other way.

\section{One prospect to bet on}

There is an urgency in the quest for new forms of the State, development and political discourse that are harmonised with (or at least not discordant with) Myanmar's historical and sociological foundations. When one looks beyond appearances, beyond the struggle between creaky and recalcitrant authoritarianism and the brave forces of democracy and liberalism, there is on the one hand the phasing out of a party system that has been the bane of the country practically since its inception during the colonial period, letting down the people continuously. The democratic leadership serves only to hasten and even facilitate the passing of an unworkable scheme. On the other hand, there is a desperate attempt to fashion a substitute. The military regime running the country in the meantime is only utilitarian, even incidental; someone has to keep things going. 
There is general agreement on the weakness of the State in Myanmar, something, moreover, that is coupled with a strong society. The prospects for strengthening the State do not seem bright for the foreseeable future, no matter how the military regime sees itself or tries to keep up appearances. Due to an unprecedented converging of circumstances, the shape of the future state structure as delineated in the principles laid down for the expected constitution includes 14 provincial (state and division) governments and legislatures as well as six smaller entities. For all its detractors, the new configuration will draw a great deal of attention and energy. Add to this the new institutions that have paradoxically emerged from the decades of internal conflict, along the lines that scholars such as Charles Tilly (1975) described. Internal conflict resulted in periodic administrative reforms, such as the great centralisation of the BSPP period. With its abject failure, a process of creative destruction can be said to be under way and a mix of centralisation and decentralisation is being propounded. In the present cycle, it is undeniable that incipient ethno-political entities have to be accommodated.

Leaving aside the fine print for the moment, Myanmar is on the brink of federalism by any other name, something much longed for and aspired to in many quarters. Barring major missteps, the scope has definitely opened up for sub-national states to grow directly out of regional societies, communities and ethnic groups.

There will be a military presence, and that of state-sponsored organisations such as the Union Solidarity and Development Association can be considered likely. But there is a good chance that the impending provincial establishments, particularly those in the ethnic regions, will be distanced from and even spared the dead hand of Bamar politics, and thereby will attain a level of viability and efficiency.

\section{Conclusion}

Bringing democracy and human rights to Myanmar cannot be equated with elevating one individual to power. Nor can it be equated with attempting to achieve political ends, however commendable in name, by means of a poverty-promotion program. 
It is to be hoped that ultimately the armed forces and the democratic parties will come to realise that state power is not something that is up for grabs and that only a stable and liberal system can set and safeguard the crucial structures and processes that order such power. In other words, institutions have to come before any single individual. For the armed forces, after being plagued by uncertainty, tension and crisis stemming from within, a hard lesson being learned is that the best assurance of its long-term integrity and stability-particularly when it comes to leadership transitions-lies with stronger state institutionalisation.

For everyone concerned, but particularly for the 'other' democrats in Myanmar, the most important thing is not to let the present stalemate become a perpetual hindrance in the larger task of building a liberal democracy. The issue of a compromise constitution will have to be faced, initiating the unending series of compromises that amount to a democracy. One of the core tasks has to be the thrashing out of a form of cohabitation. Beyond even all that, what Burmese society is engaged in -if it would only realise it more fully—surpasses what either the military institution or any political party presumes itself to be the arbiter of. The processes will not be easy, nor will the outcomes satisfy everyone. The country is faced with the overarching issue of nation building.

Assumptions are not enough and one must look beyond the hype, as well as beyond the histrionics, the polemics, the posturing and even beyond the personal suffering. In the emotion-charged atmosphere after 1988, a majority threw its support behind what seemed to be the solution. Now it is clear that fate has placed Myanmar between two grey-hued organisations, both professing a path to democracy. In both, decisions come from the top: participatory decision making is unheard of. More and more, democracy has been relegated to the status of an excuse, a window-dressing, a stage prop and a handy rallying cry. The real issue - as anywhere else-is personalities vying for power. A real concern for democratisation means concern for the plight of the people; this, it should be pointed out, is missing. 
When this is realised, the 'struggle' loses quite a bit of its meaning. What is happening now can be seen as only the inevitable working itself out. It is universally agreed that there should not be a return to an authoritarian system, but if the military should not continue with the systems, constructs and methods of the unhappy past, the same should apply for the other side-the democratic opposition.

In one sense, it is a huge disappointment. In another sense, it is a lesson learned and applied-in the nick of time. Indeed, the real business begins only now, when the dust has cleared and hot blood has cooled: the business of democratisation, that of building a unified yet decentralised nation, the bringing of the economy back on an even keel and the climbing back from developing-country status. These processes are indeed already under way. They could and should be helped along; no one who is even remotely concerned with Myanmar's future could afford to neglect them, much less hinder them. A country that has been relegated to developing-country status and has a half-century of travail behind it should not be penalised for following the most natural, realistic and feasible path before it under the circumstances. This is exactly what Myanmar has to do.

\section{Notes}

1 Consociationalism is a form of government involving group representation by élites, and is suggested for deeply divided societies. According to Rupert Taylor, 'Consociationalism advances a system of consensual multi-ethnic power sharing as opposed to majority rule.'

2 The detailed, long-term study is Transitions from Authoritarian Rule: prospects for democracy in Latin America and Southern Europe (O'Donnell and Schmitter 1986), a project of the Woodrow Wilson Center, 1979-81. It comprises four volumes of edited papers and a final volume of conclusions. 


\section{References}

Callahan, M., 2003. Making Enemies: war and state building in Burma, Cornell University Press, Ithaca.

Esteban Montes, J. and Vial, T., 2005. The Role of Constitution-Building Processes in Democratization, International Institute for Democracy and Electoral Assistance, Stockholm.

Khan, M.H. 2004. 'State failure in developing countries and institutional reform strategies', paper presented at the Annual World Bank Conference on Development Economics_Europe 2003, World Bank, Washington, DC.

O’Donnell, G.A. Schmitter, P.C. and Whitehead, L., 1986. Transitions from Authoritarian Rule: prospects for democracy in Latin America and Southern Europe, The Johns Hopkins University Press, Baltimore and London.

Tilly, C., 1975. 'Reflections on the history of European state-making', in C. Tilly (ed), The Formation of National States in Western Europe, Princeton University Press, Princeton. 